$0024-3205(95) 02226-0$

\title{
ADENYLATE CYCLASE ACTIVITY DURING EXOCRINE PANCREATIC PROLIFERATION IN THE RAT
}

\author{
I. Alvaro-Alonso, M.C. Boyano-Adánez, A. Martín-Espinosa and E. Arilla \\ Unidad de Neuroendocrinología Molecular, Departamento de Bioquímica y \\ Biología Molecular, Facultad de Medicina, Universidad de Alcalá, E-28871 \\ Alcalá de Henares, Madrid, Spain.
}

(Received in final form October 6, 1995)

\begin{abstract}
Summary
Adenylate cyclase activity in pancreatic acinar cell membranes was determined in rats that had undergone a treatment with pentagastrin $(250 \mu \mathrm{g} / \mathrm{kg}$, intraperitoneal three times daily) for 1 week or that had undergone small bowel resection (90\%) and were sacrified at 2 weeks, 1 month and 6 months after intervention. Both treatments are potent stimulators of pancreatic acinar cell proliferation. Adenylate cyclase activity was similar under basal conditions and after the diterpene forskolin stimulation in pancreatic acinar membranes from all groups studied. The ability of low concentrations of the stable GTP analogue, 5'-guanylylimidodiphosphate (Gpp[NH]p) to inhibit forskolin- stimulated adenylate cyclase activity was decreased in pancreatic acinar membranes from enterectomized rats at 2 weeks and 1 month after the operation and returned to control values at 6 months after enterectomy. Stimulation of adenylate cyclase by high concentration of Gpp[NH]p or by secretin $\left(10^{-8} \mathrm{M}\right)$ was higher in both pancreatic hyperplasia conditions as compared with control animals. These findings suggest that the coupling efficiency of the $G_{s}$ protein to adenylate cyclase from pancreatic acinar membranes is enhanced without any alterations in the catalytic activity of the enzyme during pancreatic proliferation. In addition, it is possible that the highly regulated pancreatic acinar adenylate cyclase activity may be necessary to regulate pancreatic acinar cell proliferation.
\end{abstract}

Key Words: adenylate cyclase, small bowel resection, pentagastrin, pancreas, hyperplasia

Although it is generally agreed that cyclic adenosine monophosphate (cAMP) is involved in cellular proliferation $(1,2)$, information on the role of cAMP-dependent signal transduction in regulating pancreatic acinar cell proliferation is scant. Recently, changes have been described in the cAMP levels during cell proliferation in a pancreatic cancer cell line cultured in vitro and in nude mice (3). However, evidence for cAMP-mediated stimulation of normal pancreatic acinar cell proliferation is uncertain. One strong stimulant of pancreatic acinar cell proliferation in the rat is an extensive small bowel resection $(4,5)$. In addition, pentagastrin has also been described to lead to pancreatic hyperplasia (6-8). In an intent to clarify the role of cAMP-dependent processes in exocrine pancreas growth, we sought to study some of the cellular events that result in pancreatic acinar cell cAMP production in conditions of pancreatic hyperplasia in the rat. Thus, the present study determined adenylate cyclase activity in pancreatic acinar cell membranes from enterectomized rats at 2 weeks and 1 and 6 months after surgery, and at 1 week after treatment with pentagastrin. Overall catalytic activity of the enzyme was measured using forskolin, an agent which potently stimulates the catalytic subunit of adenylate cyclase (9). Experiments were also performed to measure the ability of inhibitory GTP-binding protein $\left(\mathrm{G}_{\mathrm{i}}\right)$ to inhibit adenylate cyclase which is readily assessed at low concentrations of $5^{\prime}$-guanylylimidodiphosphate (Gpp[NH]p), a stable GTP analogue. Under such 
conditions $G_{i}$ protein is selectively activated due to the marked difference in affinity exhibited between it and stimulatory GTP-binding protein $\left(\mathrm{G}_{\mathrm{s}}\right)$ for GTP and its non-hydrolyzable analogue Gpp[NH]p. The effects of stimulating adenylate cyclase activity with either high $\mathrm{Gpp}[\mathrm{NH}] \mathrm{p}$ concentrations, or with secretin, which activate $\mathrm{G}_{s}$ proteins (10), were also studied.

\section{Materials and Methods}

\section{Chemicals}

Pentagastrin was kindly donated by ICI-Farma (Spain). Secretin, forskolin, bacitracin, phenylmethylsulphonylfluoride (PMSF), guanosine triphosphate (GTP), 5'-guanylylimidodiphosphate (Gpp[NH]p); 3-isobutyl-1-methylxantine (IBMX) and bovine serum albumin were purchased from Sigma (St Louis, MO, USA). All other chemicals were reagent grade.

\section{Animals}

Fifty male Wistar rats with an initial body weight of 200-250 g were used in this study. The animals were divided in the following groups:

a) Small bowel resection. After a 12 hour fast, animals were randomized to receive either a 90 per cent proximal small bowel resection (as measured from the ligament of Treitz) with end-to-end anastomosis or jejunal transection and resuture (5). Operations were carried out under light ether anaesthesia. A continuous 6/0 silk suture was used for intestinal anastomoses. Food was reintroduced $12 \mathrm{~h}$ after the operation. Representatives from the resection and transection groups were killed at 2 weeks, at 1 month and at 6 months. The survival rate of the operation was $80 \%$.

b) Pentagastrin. The animals received intraperitoneal injections of saline or pentagastrin (Peptavlon) $(250 \mu \mathrm{g} / \mathrm{kg})(6)$, three times daily for 1 week. This dose of pentagastrin causes maximal stimulation of DNA synthesis in the rat $(11,12)$. Rats were killed $8 \mathrm{~h}$ after the last injection.

At the time of death, the pancreas was removed and trimmed free of fat, connective tissues, and lymph nodes.

\section{Preparation of rat pancreatic acinar membranes}

Dispersed pancreatic acini were obtained from male Wistar rats after enzymatic degradation of the organ with 0.2 units of collagenase/ml in an oxygenated Krebs-Ringer medium as described by Amsterdam et al. (13). After thorough washing by sedimentation, acini were transferred to 0.3 $M$ sucrose and homogenized at $4^{\circ} \mathrm{C}$ by use of a Potter homogenizer following the Meldolesi et al. method (14). After sedimentation at $1500 \mathrm{~g}$ for $12 \mathrm{~min}$ the homogenized membranes were resuspended in $1.56 \mathrm{M}$ sucrose. This suspension was overlaid with $0.3 \mathrm{M}$ sucrose and centrifuged at $105,000 \mathrm{x}$ $\mathrm{g}$ for $150 \mathrm{~min}$. The plasma-membrane-enriched fraction collected from the interphase was diluted with distilled water and centrifuged at $13000 \mathrm{xg}$ for $30 \mathrm{~min}$. The supernatant was discarded and the pellet was resuspended in $50 \mathrm{mM}$ Tris $/ \mathrm{HCl}, \mathrm{pH} 7.4,0.01 \mathrm{mg} / \mathrm{ml}$ bacitracin, $0.2 \mathrm{mM} \mathrm{CaCl}{ }_{2}$ and stored at $70^{\circ} \mathrm{C}$.

\section{Adenylate cyclase assay}

Adenylate cyclase activity was measured as previously reported (15) with minor modifications. Briefly, rat pancreatic acinar membranes $(0.12 \mathrm{mg}$ protein $/ \mathrm{ml})$ were incubated with $1.5 \mathrm{mM}$ ATP, $5 \mathrm{mM} \mathrm{MgSO}{ }_{4}, 1 \mu \mathrm{M}$ GTP and ATP-regenerating system $(7.5 \mathrm{mg} / \mathrm{ml}$ creatine phosphate and $1 \mathrm{mg} / \mathrm{ml}$ creatine kinase), $1 \mathrm{mM}$ 3-isobutyl-1-methylxantine, $0.1 \mathrm{mM}$ PMSF, $1 \mathrm{mg} / \mathrm{ml}$ bacitracin, $1 \mathrm{mM}$ EDTA, and tested substances $\left(10^{-9} \mathrm{M} \mathrm{SS}\right.$ or $10^{-5} \mathrm{M} \mathrm{FK}$ ) in $0.1 \mathrm{ml}$ of $0.025 \mathrm{M}$ Tris/HCl buffer (pH 7.4). After $30 \mathrm{~min}$ incubation at $30^{\circ} \mathrm{C}$, the reaction was stopped by heating the mixture for $3 \mathrm{~min}$. After refrigeration, $0.2 \mathrm{ml}$ of an alumina slurry $(0.75 \mathrm{~g} / \mathrm{ml}$ in triethanolamine $/ \mathrm{HCl}$ buffer, $\mathrm{pH} 7.4)$ was added and the suspension centrifuged. The supernatant was taken for assay of cyclic AMP by the method of Gilman (16). 


\section{Data analysis}

Statistical comparisons of all the data were carried out with one way analysis of variance (ANOVA) and the Student's Newman-Keuls test. Means among groups were considered significantly different when the $\mathbf{P}$ value was less than 0.05 . Each individual experiment was performed in duplicate.

\section{$\underline{\text { Results }}$}

Rats with $90 \%$ small bowel resection weighed $9 \%$ less than controls at 2 weeks ( $247 \pm 5$ versus $270 \pm 6 \mathrm{~g}$, n.s.) and $15 \%$ less at 1 month $(272 \pm 7$ versus $320 \pm 8 \mathrm{~g}, P<0.001)$. Pancreatic growth occurred with age in all experimental groups. In sham-operated rats, pancreatic wet weight increased from $870 \pm 8 \mathrm{mg}$ at 2 wecks to $1455 \pm 10 \mathrm{mg}$ at 1 month. In rats with proximal small bowel resection, pancreatic weight was $15 \%$ and $23 \%$ greater at 2 weeks $(1305 \pm 41)$ and 1 month $(2001 \pm 66 \mathrm{mg}$, $P<0.01)$ respectively. At 6 months after $90 \%$ resection, body weights and pancreatic wet weights of sham-operated and resected animals did not differ significantly. The pancreatic weight in the pentagastrin-treated group $(862 \pm 9 \mathrm{mg})$ was increased by approximately $32 \%$ as compared with the control group $(1138 \pm 10 \mathrm{mg})$.

Mitotic figures have been observed in acinar cells after proximal small bowel resection and pentagastrin administration while they were absent in controls. Mitoses were never present in cells other than acinar cells and in enterectomized rats, they were seen only at 2 weeks of resection.

Pancreatic acinar cell membranes exhibited similar basal adenylate cyclase activity in all groups studied. The diterpene forskolin, which directly stimulates the catalytic unit of adenylate cyclase, magnified the adenylate cyclase activity in membranes from control and treated animals by roughly the same amount (Fig. 1).

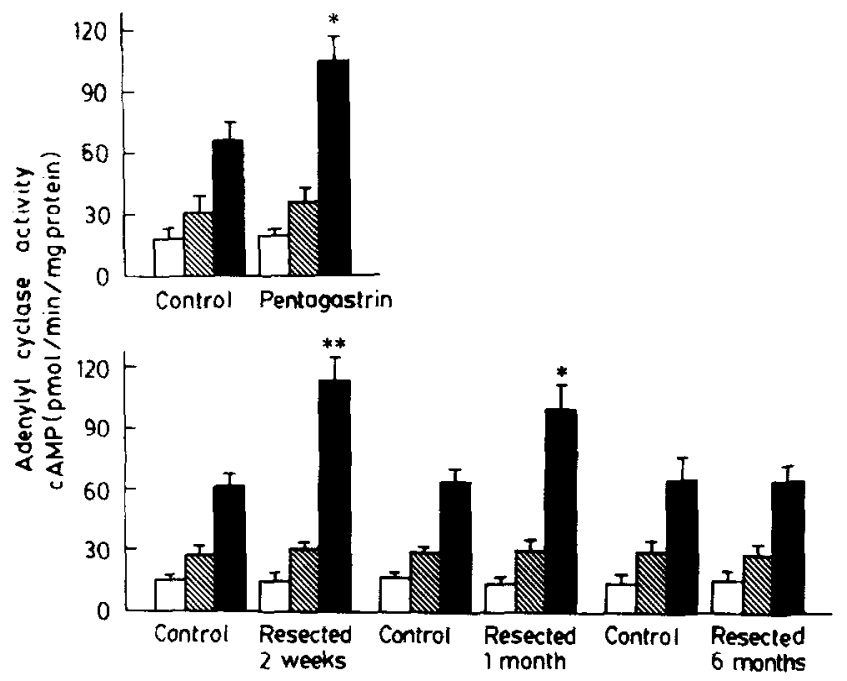

FIG. 1

Effect of $10^{-5} \mathrm{M}$ of forskolin (hatched bars) and $10^{-8} \mathrm{M}$ of secretin (black bars) on adenylate cyclase activity in pancreatic acinar membranes of pentagastrin-treated rats (A) or animals subjected to small bowel resection and studied 2 weeks and 1 and 6 months after surgery (B). Open columns correspond to the control conditions. The asterisk indicates a significant difference $(p<0.05)$ between the control and resected groups. The results are the mean $\pm S E M$ of six experiments with membranes from different animals. 
Secretin stimulated the adenylate cyclase activity in pancreatic acinar cell membranes in all groups studied. However, the effect of secretin on adenylate cyclase activity was markedly increased in pancreatic acinar membranes from enterectomized rats at 2 weeks and 1 month after the operation and in pentagastrin-treated rats as compared with their respective controls (Fig. 1).

Stimulation of adenylate cyclase by high concentrations of $\mathrm{Gpp}[\mathrm{NH}] \mathrm{p}$, which fully activates $\mathrm{G}_{s}$, achieved a higher activation of adenylate cyclase activity in membranes from enterectomized rats at 2 weeks and 1 month after the operation (Fig. 2), as well as in the pentagastrin-treated rats as compared with the respective controls (Fig. 3). At 6 months after the operation, the stimulation of adenylate cyclase by high concentrations of Gpp[NH]p returned to control values (Figs. 2 and 3 ).

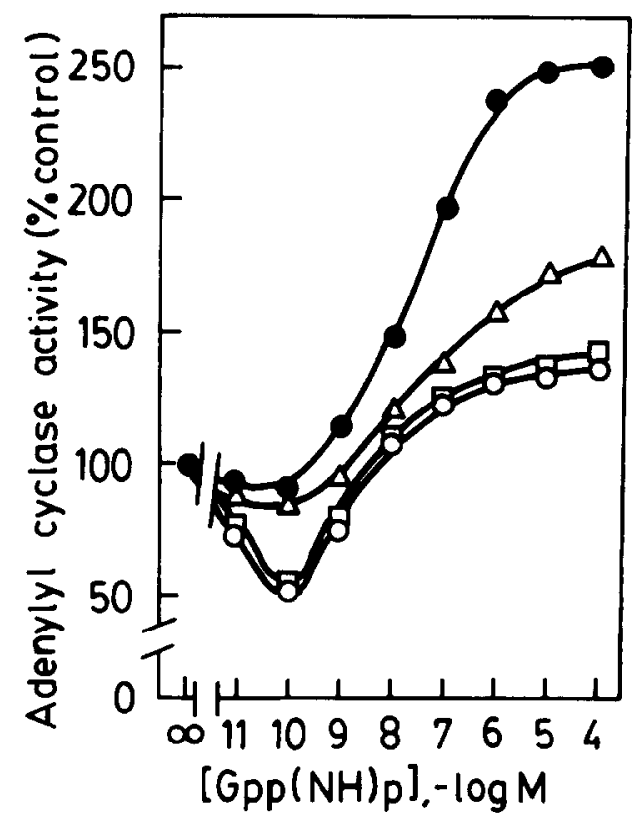

FIG. 2

Dose effect curves for 5'-guanylylimidodiphosphate (Gpp[NH]p) on forskolinstimulated adenylyl cyclase activity in rat pancreatic acinar cell membranes of shamresected rats $(0)$ and animals subjected to small bowel resection and studied 2 weeks $(O)$ and $1(\Delta)$ and $6(\square)$ months after surgery. Data are expressed as a percentage of forskolin-stimulated activity $(100 \%)$ in the absence of Gpp[NH]p. Each point is the mean of six experiments with membranes from different animals. The results express the values of a pool of the control groups, since differences among them were not found. For the sake of clarity, SEM are not represented but were always below $9 \%$ of the mean values.

Low concentrations of $\mathrm{Gpp}[\mathrm{NH}] \mathrm{p}$ selectively activate $\mathrm{G}_{\mathrm{i}}$ proteins, thus leading to the inhibition of forskolin-stimulated adenylate cyclase activity. Pancreatic acinar cell membranes from shamoperated animals showed a well-defined inhibitory effect on forskolin-stimulated adenylate cyclase activity at low Gpp[NH]p concentrations (Fig. 2). In contrast, when pancreatic acinar cell membranes were used from enterectomized animals 2 weeks or 1 month after the operation, the low concentrations of $\mathrm{Gpp}[\mathrm{NH}] \mathrm{p}$ failed to exert an inhibitory effect on forskolin-stimulated adenylate cyclase activity. Inhibition was recuperated at 6 months after intestinal surgery (Fig. 2). 


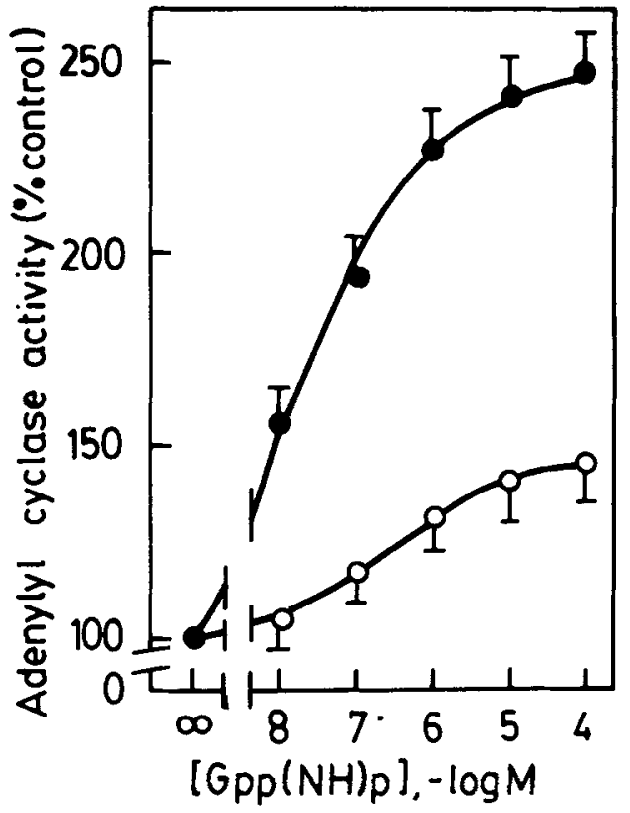

FIG. 3

Stimulation of adenylyl cyclase activity from rat pancreatic acinar cell membranes with high concentrations of 5'-guanylylimidodiphosphate (Gpp[NH]p). Membranes from control, and pentagastrin-treated rats were used. Results are means $\pm S E M$ of six experiments with membranes from different animals.

\section{Discussion}

Although CAMP has been recognized as a second messenger for decades, the role of cAMPdependent signal transduction in the regulation of compensatory pancreatic acinar cell proliferation remains uncertain. Therefore in the present study, adenylate cyclase activity was determined in two conditions of pancreatic hyperplasia in the rat: small bowel resection (5) or pentagastrin (6) administration.

The inhibitory effect of low concentrations of Gpp [NH]p on forskolin-stimulated adenylate cyclase was markedly decreased in pancreatic acinar cell membranes from enterectomized rats 2 weeks and 1 month after resection. This finding suggests that there is an abnormality at the $G_{i}$ protein level in the membranes that would explain the decreased inhibition of adenylate cyclase by low $\mathrm{Gpp}[\mathrm{NH}] \mathrm{p}$ concentrations.

The mechanism(s) by which $\mathrm{G}_{\mathrm{i}}$ protein is altered 2 weeks after small bowel resection is not clear. A covalent modification of the $\alpha$-subunit, such as a change in phosphorylation, might cause the alteration. On the other hand, ADP ribosylation, which is possibly a physiologically important mechanism for the regulation of $G$ protein activity, might affect $G_{i}$ in the post-enterectomy pancreatic hyperplasia. Another possibility is the sequestration of $G_{i}$ protein. It has recently been shown that growth-factor induced cell division is parallelled by translocation of $G_{i}$ from the plasma membrane to the nucleus and this leads to a loss of $G_{i}$ protein activity in the plasma membrane (17). The possibility that such a translocation took place in the exocrine pancreas after subtotal enterectomy simultaneous to strong cellular proliferation is a possibility that still must be confirmed. Previous studies by our group have found that the ability of Gpp $[\mathrm{NH} \mid \mathrm{p}$ to inhibit forskolin-stimulated adenylate cyclase activity was also decreased in pancreatic acinar cell membranes from pentagastrin-treated rats (18).

The functionality of $\mathrm{G}_{\mathrm{s}}$ proteins during small bowel resection and pentagastrin administration was tested on the basis of the capacity of high concentration of Gpp [NH]p to stimulate adenylyl 
cyclase activity in pancreatic acinar membranes from control, enterectomized-and pentagastrin-treated rats.

The present study found that the exocrine pancreatic hyperplasia observed following proximal small bowel resection or pentagastrin administration is accompanied by an increase in the stimulatory effect of high concentrations of $\mathrm{Gpp}[\mathrm{NH}] \mathrm{p}$ on adenylate cyclase activity, with no changes in forskolinstimulated adenylate cyclase activity, in pancreatic acinar cell membranes. These findings indicate that the coupling efficiency of the $G_{s}$ protein to adenylate cyclase is enhanced without there being any alterations in the catalytic unit of adenylate cyclase at 2 weeks and 1 month after enterectomy or after the administration of pentagastrin. The increased $\mathrm{G}_{s}$ protein coupling may be due either to alterations in the affinity of Gpp $[\mathrm{NH}] p$ for the $\mathrm{G}_{\mathrm{s}}$ protein or, alternatively, to increases in the $\mathrm{G}_{\mathrm{s}}$ protein levels. However, since no alteration was seen in the $\mathrm{EC}_{50}$ values of $\mathrm{Gpp}[\mathrm{NH}] \mathrm{p}$, the latter explanation seems more plausible.

The present study showed increased functional activity of $G_{s}$ protein and decreased activity of $G_{i}$ protein in pancreatic acinar membranes. Therefore, the $G_{s} / G_{i}$ ratio is markedly increased as compared with the controls. It has been suggested that the $\alpha_{i}$ subunit of $\mathrm{G}$ proteins can modulate the stimulatory effect of $\alpha_{\mathrm{s}}$ on the adenylyl cyclase enzyme (19). The observed decrease of the inhibitory effect of low concentrations of Gpp[NH]p on FK-stimulated adenylyl cyclase in pancreatic acinar membranes from small bowel resection and pentagastrin-treated rats is in concordance with the increase of adenylyl cyclase activity at high concentrations of Gpp[NH]p. Other authors have also reported that the amounts of $\mathrm{G}_{\mathrm{s}}$ proteins increase during liver regeneration $(20,21,22)$.

It should be mentioned that it has been observed in other models that the level and function of $G$ proteins is regulated and that this regulation could modulate cell responsiveness. Although the present results suggest that adenylate cyclase activity in pancreatic acinar membranes is regulated after small bowel resection or pentagastrin administration, its role in regulation of pancreatic proliferation is uncertain.

The growth-stimulating effect of cAMP may involve induction of growth-related gene expression. CAMP-responsive elements have been identified "upstream" of several protooncogenes (23), and the catalytic unit of a cAMP-dependent kinase positively regulates $c$-fos expression (24).

In addition to exocrine pancreatic hyperplasia following enterectomy, the pancreatic acinar cells must continue to perform specific exocrine pancreas functions while the pancreas proliferates. It is generally agreed that CAMP is involved in the intracellular control of pancreatic bicarbonate secretion (25). Gelinas et al. (26) have shown that 4 weeks after a $75 \%$ resection, the bicarbonate output is still significantly higher in resected rats than their controls. Our data indicate that exocrine pancreas adenylate cyclase activity increases significantly during the first 2 and 4 weeks after small bowel resection and returns to control values at 6 months. These findings suggest that the coupling efficiency of adenylate cyclase to the $G_{s}$ protein is enhanced by hyperplastic pancreas although the catalytic activity of the enzyme was unchanged.

\section{Acknowledgements}

We thank Ms Carol F. Warren from the Alcalá de Henares University Institute of Education Science and Lilian Puebla Jiménez for their linguistic assistance. This work was supported by a grant (PB94-0339) from the Dirección General de Investigación Científica y Técnica of Spain.

\section{$\underline{\text { References }}$}

1. D.L. FRIEDMAN, Handb. Exptl. Pharmacol. 58/II, 151-188 (1982).

2. A. BOYNTON and J.F. WHITFIELD, Adv. Cyclic. Nucleot. Res. 15 193-294 (1983).

3. A. ESTIVAL, P. MOUNIElOU, V. TROCHERIS, J.L. SCEMAMA, F. ClEMENTE, E. HOLLANDE and A. RIBET, Biochem. Biophys. Res. Commun. 111 958-963 (1983).

4. P. HAEGEL, C. STOCK, J. MARESCAUX, B. PETIT and J.F. GREINER, Gut 22 207212(1981). 
5. P. WATANAPA, K. BEARDSHALL, J. CALAM and R.C.N. WILliAMSON, Br. J. Surg. $\underline{78}$ 917-920 (1991).

6. P.D. MAYSTON and J.A. BARROWMAN, Gastroenterology 64 391-399 (1973).

7. T. LEHY and F. PUCCIO, Regul. Pept. 27 87-96 (1990).

8. J.R.Jr UPP, G.J. POSTON, D.G. MAC LELLAN, C.M.Jr TOWNSEND, S.C. BARRANCO and J.C. THOMPSON, Pancreas $\underline{3}$ 193-198 (1988).

9. K.B. SEAMON and J.W. DALY, Advances in Cyclic Nucleotide and Protein Phosphorylation Research 17 1-150, Raven Press, New York (1986).

10. E.R. TRIMBLE, R.BRUZZONE, T.J. BIDEN and R.V. FARESE, Biochem. J. 239 257-261 (1986).

11. L.R. JOHNSON and P.D. GUTHRIE, Gastroenterology 67 453-459 (1974).

12. A. DEMBINSKI, Z. WARZECHA, S.J. KONTUREK, R-Z CAI and A.V. SCHALLY, J. Physiol. Pharmacol. 42 195-209 (1991).

13. A. AMSTERDAM, T.E. SOLOMON, and J.D. JAMIENSON, Methods Cell Biol. 20 361-378 (1978).

14. J. MELDOLESI, J.P. JAMIESON and G.E. PALADE, J. Cell. Biol. 49 109-158 (1971).

15. M.D. HOUSLAY, J.C. METCALFE, G.P. WARREN, T.R. HESKETH and G.A. SMITH, Biochim. Biophys. Acta 436 489-494 (1976).

16. A.G. GILMAN, Proc. Natl. Acad. Sci. USA 67 305-312 (1970).

17. M.F. CROUCH, D.A. BELFORD, P.J. MILBURN and I.A. HENDRY, Biochem. Biophys. Res. Commun. 167 1369-1376 (1990).

18. I. ALVARO-ALONSO, G. MUÑOZ-ACEDO and E. ARILlA, Regul. Pept. 54 479-487 (1994).

19. L. BIRNBAUMER, Annu. Rev. Pharmacol. Toxicol. 30 675-705 (1990).

20. L.G. GUIJARRO, A. COUVINEAU, M.S. RODRIGUEZ-PENA, M.G. JUARRANZ, N. RODRIGUEZ-HENCHE, E. ARILLA, M. LABURTHE and J.C. PRIETO, Biochem. J. 285515 520 (1992).

21. A.M. DIEHL, S.Q. YANG, D. WOLFGANG and G. WAND, J. Clin. Invest. $\underline{89}$ 1706-1712 (1992).

22. T. YAGAMI, S. KIRITA, A. MATSUSHITA, K. KAWASAKI and Y. MIZUSHIMA, Biochim. Biophys. Acta 1222 81-87 (1994).

23. L.C. CANTLEY, K.R. AUGER, C. CARPENTER, B. DUCKWORTH, A. GRAZIANI, R. KAPELLER and S. SOLTOFF, Cell 64 281-302 (1991).

24. K.T. RIABOWOL, J.S. FINK, M.Z. GILMAN, D.A. WALSH, R.H. GOODMAN and J.R. FERAMISCO, Nature (Lond) 336 83-86 (1991).

25. H. KOFOD, Acta Endocrinol. 126 Suppl 1, 9-41 (1992).

26. M.D. GELINAS, C.L. MORIN and J. MORISSSET, J. Physiol. $\underline{322} 71-82$ (1980). 